\title{
Liberty - security dilemmas and party cohesion in the European Parliament
}

\author{
Mihail Chiru ${ }^{1}$, Oxford School of Global and Area Studies, University of Oxford, UK \\ Valentin Stoian², Bucharest Centre for Political Theory, Bucharest, Romania
}

\begin{abstract}
The European Parliament is increasingly a central actor in attempts to regulate surveillance and find the balance between safeguarding personal freedoms and ensuring EU citizens' security. However, virtually nothing is known about what drives the positions of MEPs on this issue, or about how European parties' cohesion is affected by this controversial topic. We explore this subject and propose a novel theoretical framework focused on the interplay between the characteristics of the two principals of the MEPs - European party groups and national parties. We test the model by analyzing the votes held on the two most salient directives adopted in this field. The findings indicate that national parties' ideological positions, and the differences between them and the European parties in the salience assigned to human rights and law and order, predict to a great extent both MEP votes on the directives and dissent from the European party line.
\end{abstract}

\section{Acknowledgments}

The authors are grateful to Thomas Winzen, Mechthild Roos, Sergiu Gherghina, Matt Hann and the two anonymous reviewers for their useful comments and constructive suggestions on earlier drafts.

\section{Funding}

Mihail Chiru' s work was supported by the Universit catholiqué de Louvain through the 'MOVE-IN Louvain' Incoming Post-doctoral Fellowship, co-funded by the Marie Curie Actions of the European Commission.

\footnotetext{
${ }^{1}$ Corresponding author. Email address: mihail.chiru@area.ox.ac.uk, phone: 07518407676; postal address: 11 Bevington Road, Oxford UK, OX2 6NB.

${ }^{2}$ Email address: valentin.stoian@ @otmail.com; postal address: Bd. Timisoara nr 11, B3, sc. 2, apt. 27, sector 6, Bucharest, Romania.
} 


\section{Introduction}

The European Parliament is increasingly becoming one of the central actors in the pan-European attempts of regulating surveillance and finding the balance between safeguarding personal freedoms and ensuring the security of EU citizens. While the institutional positions and policy shifts of the European Parliament (EP) on these matters have been studied, we know virtually nothing about what drives the positions of individual MEPs or how European party groups' cohesion is affected by this controversial topic (Ripoll Servent 2013; Ripoll Servent and MacKenzie 2011).

The paper argues that the increase in acts of international terrorism and the recurrent revelations about extensive government surveillance have the potential to trigger a significant challenge to the cohesion of parties structured along established ideological divides. In the EP this challenge can be even more severe given that European Party Groups (EPGs) and national parties might not only have different preferences due to specific national experiences with terrorism and the varying popularity of the demands for a new 'social contract' on surveillance, but might also assign different salience to these issues.

We show that the voting decisions of the Members of the European Parliament (MEPs) on surveillance policies are shaped by their national parties' positions on the pro- vs. anti-EU and GAL-TAN dimensions and by differences in issue salience between their two party principals, regarding human rights, constitutionalism and law and order (Klüver and Spoon 2015).

To illustrate this point we concentrate on 28 roll-call votes held on two of the most salient directives adopted by the European Parliament in the field of surveillance and the fight against terrorism: Directive2006/24/EC on the retention of data generated or processed in connection with the provision of publicly available electronic communications services and Directive 
2016/681/EU on the use of passenger name record (PNR) data for the prevention, detection, investigation and prosecution of terrorist offences. Our main aim is to assess what made the MEPs vote in favor or against the directives and what motivated their dissent from the EPG line in these votes.

Policy change in the Area of Freedom, Security and Justice (AFSJ) is particularly interesting to investigate given the counter-intuitive outcomes which the inclusion of the EP has generated. While the participation of the EP in decision-making in AFSJ through the expansion of co-decision after 2005 was expected to lead to more liberal outcomes, the opposite result was achieved. Thus, since becoming a fully-fledged actor in AFSJ decision-making, the EP, once described as an "institutionalized NGO" (Ripoll Servent 2015, 126), was co-opted to the side of "responsibility" and voted in a series of cases for more stringent regulations in favor of the security apparatuses of national states. While several studies (Ripoll Servent 2013, 2015, Trauner and Ripoll Servent 2015) analyzed the EP's positions in relation to the Commission and the Council, little is known about the factors that determined the MEPs' individual votes on these matters.

Our results emphasize that there is a relatively strong correspondence between what national parties advertise in their European elections manifestos and how their representatives vote in the EP on matters regarding surveillance policies. This link in the programmatic linkage also causes part of the dissent from EPGs when the above-mentioned differences in issue salience occur.

The context of the votes analyzed here is represented by a number of policies increasing the power of the security apparatus in the US and the EU and their legal contestation. After the introduction we present this context and a summary of the two directives. Next, we discuss the 
hypotheses of the study. The third section details the research design. Then we present the results of the multivariate analyses of what explains pro-security votes and what motivates dissent. The conclusion discusses the main findings and further directions of research.

\section{Surveillance policies in the post-Snowden era: advances and contestations.}

In recent years we have witnessed an unprecedented number of disclosures, scandals and demands for accountability regarding issues concerning national security, intelligence and surveillance. Especially after the revelations of US whistleblower Edward Snowden, a new 'social contract' on the permissible limits of government surveillance and data collection is being demanded by human rights groups and political parties alike (Poitras 2013). In 2013-2014 Snowden revealed a series of documents which showed that the US government collected vast amounts of communications data (the communications metadata and the actual content of communications) from both foreign and domestic sources. Particularly egregious was the PRISM surveillance program. Snowden revealed how the NSA tapped into the communications infrastructure of several US communications companies to record information travelling through them. Further disclosures showed that the US government spied for over a decade on the telephone communications of German Chancellor Angela Merkel.

In the US, these leaks sparked not only a public outcry, but also several waves of litigation against the National Security Agency's interception program. Most famously, the ACLU v. Clapper case involved a petition from US human rights group American Civil Liberties Union, demanding that the wide-ranging NSA program be stopped. The US Court of Appeals for the Second Circuit maintained that the bulk collection program violated Section 215 of the American Patriot Act, but did not rule on the constitutionality of the program. On the moment 
this section expired, the US Congress enacted the US Freedom Act, which limited to some extent the scale of the NSA metadata collection.

In addition to the US challenges, a number of cases have been brought in Europe against policies such as metadata retention, both in the European Court of Justice and in national courts. Metadata retention laws and practices have been challenged with various forms of success in Bulgaria, Romania, Cyprus, Czech Republic, Germany and the United Kingdom and have generated public anxiety on each occasion (Stoian 2015). The most important case was, however, Digital Rights Ireland, which led to the invalidation of Directive 2006/24 on the grounds that it enforced a disproportionate means for the legitimate goal of combating terrorism. In the following lines we present the contents and legal fate of the directives that are the focus of this article.

\section{The Directives}

The first Directive analyzed in this article is Directive 2006/24/EC, which was adopted on the $14^{\text {th }}$ of December 2005 and regulated the retention of and access to communication metadata from telecommunications providers by national law-enforcement agencies. According to the Directive, Member States were to create a legislative framework that would impose on telecommunications providers an obligation to store telecommunications metadata for up to two years (Directive 2006/24/EC - Articles 3 and 6). Thus, providers would have to keep, and relevant authorities of Member states could access, "traffic and location data on both legal and natural persons and the related data necessary to identify the subscriber or registered user" (Directive 2006/24/EC - Article 1). Finally, the Directive did not regulate explicitly how this data could be accessed by national law enforcement and intelligence authorities. 
Eventually, through the April 2014 Digital Rights Ireland judgment, The European Court of Justice invalidated the Directive. It argued that it breached the rights to privacy as stipulated in Article 8 or the European Charter of Fundamental Rights for several reasons. The Court criticized the generality of the Directive, which allowed use of data without any restriction on the potentially targeted persons or on the type of data that could possibly be retained. Further, the Court also complained that the Directive "does not require any relationship between the data whose retention is provided for and a threat to public security and, in particular, it is not restricted to a retention in relation (i) to data pertaining to a particular time period and/or a particular geographical zone and/or to a circle of particular persons likely to be involved, in one way or another, in a serious crime, or (ii) to persons who could, for other reasons, contribute, by the retention of their data, to the prevention, detection or prosecution of serious offences." (Cases C-293/12 and C-594/12 - Digital Rights Ireland v. Minister for Communications, Marine and Natural Resources). Finally, the Court also criticized the fact that the directive "does not require the data in question to be retained within the European Union". These reasons allowed the Court to declare the Directive to be disproportionate to the legitimate means pursued and to declare it invalid (Stoian 2015). A subsequent decision, C-203/15 - Tele2 Sverige carried the logic even further and completely banned blanket metadata retention and use across the Union. Only the targeted use of metadata is, in the view of the ECJ, compatible with the Charter of European Fundamental Rights.

The Data Retention Directive was the first of its kind adopted under a co-decision procedure, after the inter-governmental transitional period allowed by the Treaty of Amsterdam had lapsed (Ripoll Servent 2015, 69). Moreover, the debate in the LIBE committee was overturned in the 
plenary, which adopted a radically different text and caused rapporteur Alvaro to request that his name be withdrawn from the report (European Parliament, 2005)

The pre-history of the PNR regulation begins in 2007, with a Commission proposal, for which the Parliament required a better justification (EDRI 2011). The Commission proposed a new regulation in 2011, which was voted down in the LIBE Committee in April 2013 for being disproportionately in favor of security, a decision ratified by the plenary in June 2013. Under pressure from the European Council, and in the aftermath of the Charlie Hebdo attacks, the EP accepted the re-opening of the issue in early 2015 by agreeing on a common position and beginning negotiations with the Council. The 2015 Paris attacks greatly sped-up the process and inter-institutional agreement was reached in December 2015 (European Parliament n.d.). Finally, the Passenger Name Record Directive was adopted in April 2016, on the same day as the General Data Protection Package. The PNR directive regulates the establishment of a data record for airplane passenger travelling to EU member states from outside the EU. Like its predecessor, the PNR directive aims to combat terrorism, to "ensure security, to protect the life and safety of persons, and to create a legal framework for the protection of PNR data with regard to their processing by competent authorities" (Directive (EU) 2016/681- Recital 5).

The directive requires Member States to establish a Passenger Information Unit (PIU), which will be entrusted with "collecting PNR data from air carriers, storing and processing those data and transferring those data or the result of processing them to the competent authorities" (Directive (EU) 2016/681- Article 4(2a)) and "exchanging both PNR data and the result of processing those data with the PIUs of other Member States and with Europol" (Directive (EU) 2016/681- Article 4 (2b)). In order to safeguard privacy, data will be extracted from the air carriers through the "push" method, which implies that "air carriers transfer ('push') the required 
PNR data to the authority requesting them, thus allowing air carriers to retain control of what data is provided" (Directive (EU) 2016/681- Article 8). Furthermore, a dedicated data protection officer, "responsible for monitoring the processing of PNR data and implementing relevant safeguards" has to be designated at each PIU (Directive (EU) 2016/681- Article 5). The Directive stipulates a maximum retention period of five years but also orders air carriers to depersonalize data after six months, by eliminating information about the identity of the flyer, which can be revealed only after judicial authorization (Articles 12 and 13, Directive EU 2016/681). While the directive itself has not been challenged in court, an EU-Canada PNR agreement allowing the transfer of PNR data to Canada has been referred by the EP to the ECJ and received an unfavorable preliminary opinion from the Court's Advocate - General.

In addition to the two directives, governance in the area of police/ counter-terrorist cooperation consists of a complex set of regulations, such as the Schengen Convention, the Prüm Convention, which created wide databases like the Visa Information System, the Schengen Information system and Eurodac (Balzacq and Leonard 2013) and framework decisions adopted before the supra-nationalization of policy-making (e.g. Framework Decision on combating terrorism (2002/475/JHA), Framework Decision 2002/629/JHA on trafficking in human beings) (Monar 2014, 198). It also includes the creation of inter-governmental agencies which were later incorporated in European law (Europol and Frontex) as well as inter-governmental practices of intelligence sharing through multi-lateral formats such as Club de Berne (CdB) and Counterterrorism group (CTG) (Svendsen 2013). Nevertheless, we focus on the two directives because they were adopted through a public decision-making process in the EP, rather than through intergovernmental negotiations. Second, the DRD was the first directive adopted in this area under co-decision, and the EP, which was expected to pursue a more liberal regulation, was co-opted to 
the side of "responsibility" (Ripoll Servent 2013). Third, the EU PNR was a crucial piece of legislation adopted after the Digital Rights Ireland decision of the CJEU. Parliament took note of this decision and the direct impact it had on the PNR in 2015, as it mentioned the phrase "the relevant case law of the Court of Justice", in direct connection to the PNR directive in its resolution on the European Agenda on Security (European Parliament 2015). Fourth, the directives are relevant for study because they represent instances in which that the European Parliament chose not to use the high justiciability of the matters to obtain a strongly liberal position as opposed to the Council's pro-security stance. While this is described by Ripoll Servent $(2015,45,78)$ in the case of the DRD votes, there is no equivalent research on the role of the EP in the PNR directive negotiations. However, a similar phenomenon is outlined by Santos Vara (2013) for the negotiations on the PNR transfer agreement between the EU and the US. Furthermore, both directives constituted cases in which the EP had a high sensitivity to failure. The DRD came in the wake of a wave of terrorist attacks in Madrid (March 2004) and UK (July 2005), while the PNR directive was adopted after another wave of terrorism, including attacks in Paris (January and November 2015) and Brussels (March 2016).

\section{Theoretical Framework}

How MEPs vote and the determinants of dissent at roll-call votes represent one of the most studied areas of EP legislative behavior (Faas 2003; Hix 2004; Lindstädt et al. 2012; Mühlböck and Yordanova 2015). In contrast, a specific focus on MEPs' voting behavior on security issues has been missing. This is why the paper takes a double aim and formulates hypotheses both with respect to the likelihood of MEPs to vote in favor of the directives and with respect to dissent in these votes. 
The Hix-Lord bi-dimensional model of EU politics maintains that the left-right and the pro-anti EU dimensions structure political competition in the EP (Marks and Steenbergen 2002). This model has indeed received much more empirical support than its alternatives (Otjes and Van Der Veer 2016). In the specific case of security policies, we argue that national parties' position on the European dimension is bound to matter greatly for whether the MEPs support an EU-coordinated extension of surveillance or not. On the one hand, Eurosceptic parties might support the directives because they give more power to national governments instead of any EU agency. On the other hand, it seems more probable that MEPs from Eurosceptic national parties would oppose the directives, because they perceive them as another step in the legal intertwining and European cooperation between Member States, which will eventually lead to a shift of competences to Brussels and less national sovereignty (Roger et al 2017). Moreover, another element pointing in the same direction is that in issues of data protection, the distinction between radical right and radical left Eurosceptic parties is probably blurred by the fact that some radical right groups are libertarian and, therefore, against the intervention of the state in the private sphere $^{3}$.

Previous research has shown that a national party's position on the 'new politics' dimension, or GAL-TAN axis is a better predictor of its preferences regarding EU security issues ${ }^{4}$, such as asylum policy, than the left-right dimension (Hooghe et al 2002: 972; Hix 2001: 683). ${ }^{5}$ There are good reasons to believe that this holds in the case of the two directives discussed here, too. National parties closer to the authoritarian end of the scale value law and order greatly and this

\footnotetext{
${ }^{3}$ We thank one reviewer for indicating this point to us.

${ }^{4}$ Security issues are less structured by left-right, given their collective good character.

${ }^{5} \mathrm{Hix}$ and Noury (2007) make a similar argument regarding the importance of the GAL-TAN position for MEPs' voting on migration policies. Nevertheless, comparing counter-terrorism and data protection policies with migration or asylum policies should be done with caution, because the dynamics inside the EPGs are dissimilar - with more open divisions within the groups on issues of migration than terrorism (Ripoll Servent 2015).
} 
could make them instruct their MEPs to vote in favor of these pro-security directives. Conversely, national parties, with a more libertarian outlook, who brand themselves as 'protectors of civil liberties' will likely instruct their MEPs to vote against.

Overall, we expect however that placement on the EU integration dimension would mater more than GAL-TAN position as an explanatory factor of MEPs' voting behavior in security issues. This would happen because how a national party relates to EU integration generally and to measures proposed by the EU actors shapes their reactions prior to judging the content of the measures (Brack 2015: 341). Thus, even if a more authoritarian-leaning party values security measures, if it is Eurosceptic it would be reluctant to endorse them because they bring along 'more Europe'.

H.1: The national parties' position on the EU dimension predicts the individual legislators' voting behavior on directives more strongly than their placement on the Gal/Tan dimension.

Nevertheless, beyond the parties' placement on the two dimensions, specific issue salience is also likely to matter in the MEPs' vote decisions (Klüver and Spoon 2015). In this respect we argue that the weight parties place on respecting constitutional provisions and human rights would influence their opposition to pan-European security measures if the latter are perceived as not offering sufficient guarantees to protect civil rights. Thus, MEPs from national parties which attach a lot of salience to human rights issues and constitutional freedoms would be more likely to oppose the extension of surveillance and vote against the directives. Conversely, the MEPs would support the directives when the fight against crime in general, and terrorism in particular, is a priority for their national party and an element that distinguishes it in the national competition. This is because the salience and position on law and order issues represent key 
components of the GAL-TAN continuum discussed above. Therefore, MEPs from parties assigning high salience to law and order should be keen to support the directives.

H.2: The more national parties emphasize human rights and constitutionalism in their manifestos and the less salient law and order issues are, the more their MEPs will oppose the directives.

Our last hypothesis refers to the causes of dissent from the EPG line in the two sets of votes. While generally there is a stronger attitudinal link between the MEPs and their national parties, there are stronger regulatory links with the EPGs, who issue voting instructions more often than national parties (Rasmussen 2008). However, on issues that are salient to them, national parties are also likely to instruct their MEPs. As a consequence, voting dissent is most likely to occur when there is a divergence in the preferences of two principals of the MEP: the EPG and the national party (Hix 2002). Thus, it is not surprising that previous studies (Hix 2002; Faas 2003; Hix 2004; Lindstädt et al. 2012; Meserve et al. 2017) have shown that policy conflict between the national party and the EPG is a major predictor of MEP defection at roll call votes. ${ }^{6}$ These studies have measured policy conflict using the distances between the two principals of the MEP on the left-right scale and on the EU integration dimension. As we have argued, the overall position on the left-right scale is less likely to matter for security policies than the placement on the European dimension. Thus, while we control for left-right ideological distance, we expect the

\footnotetext{
${ }^{6}$ See however also Coman (2009), who argues that in contested votes - votes on which the national party and the EPG have different positions - higher ideological distance on the left-right and EU integration dimensions between the two principals leads to following the EPG line and dissenting from the national party.
} 
distance on the pro-anti EU scale between the national party and the European group to shape dissent on these votes.

However, we also argue that when assessing the policy conflict between the national and the European party it is necessary to also consider a different type of distance. Thus, given the content of the two directives, dissent is also more likely to occur when there are large differences between the two principals in the salience they assign to human rights and constitutionalism issues on the one hand, and law and order, including the fight against terrorism, on the other. This approach is inspired by the work of Klüver and Spoon (2015) who analyzed roll-call votes taken in the EP from 1979 until 1999 on four issue areas - agriculture, environment, social policy and external trade. They found that MEPs were significantly more likely to dissent on issues that are salient to their national parties. Nevertheless, because national parties are also more likely to affiliate to EPGs that assign high salience to the same set of issues, what should matter more specifically for dissent are those cases in which the two principals value an issue differently. Therefore, we argue that dissent in the votes on the surveillance directives will also be driven by differences in the salience assigned by the two principals to human rights, constitutionalism and law and order.

H3a: The larger the distance between the NP and the EPG on EU integration, the more likely the MEP will dissent from the EPG line.

H3b: The larger the difference in saliency awarded to human rights, constitutionalism and law and order between the NP and the EPG, the more likely the MEP will dissent from the EPG line.

Beyond the above hypotheses, we control for a number of individual and party-related factors that could affect the support for and the dissent on the directives. These include: the MEP's 
membership in a committee that discussed the directives, the MEP's length of EP experience, the MEP's position in the EP power structure, electoral marginality, the left-right placement of the national party and the distance on this scale between the national party and the EPG, whether the national party is in government, the size of the national party delegation, whether the MEP comes from a new Member State, belongs to the Grand Coalition or shares the EPG affiliation with the directive rapporteur.

EP committee membership is best predicted by the informational theory of assignment (Yordanova 2013) and EPGs usually follow their members' votes in the relevant committee in the plenary vote. Because of this, we would expect MEPs serving in committees that discussed the directives to dissent less. However, the opposite expectation, including not only dissent but also opposition to the directives, might hold if these MEPs' opinions were not incorporated in the EPG leadership decisions regarding the votes on the directives. In the DRD case we know that 'the LIBE committee was very cohesive in its opposition to the Council's position', (Ripoll Servent 2013: 977) which nevertheless prevailed, because the two largest EPGs (EPP-ED and PES) accepted it, hoping for future negotiations gains in the Area of Freedom, Security and Justice and because they wanted the EP to be perceived as a 'responsible partner' of the Council in the fight against terrorism (Ripoll Servent 2013).

Socialization has been emphasized to foster voting cohesion by many parliamentary studies (Hix 2004; Gherghina and Chiru 2014). Similarly, positive selective incentives, such as distributing mega-seats, represent an instrument used by party leaders to create cohesion. Thus, MEPs who hold leadership positions are expected to defect less because the EPGs control the allocation of these offices. In the EP context, in which re-election depends almost entirely on the will of the national parties and any electoral connection is virtually absent (Hix and Høyland 2013: 184) 
electoral marginality should make MEPs more likely to defect when the EPG line contradicts the national party's preferences.

Participating in government could boost support for increased surveillance powers. Thus, for opposition politicians it is less costly to be critical of the expansion of government powers, while governments, being responsible for defense against terrorism, cyber-attacks or foreign espionage, tend to support such measures, in order to avoid any future blame regarding a failure to protect their citizens (Ripoll Servent and MacKenzie 2017). With respect to the effect of governing national party on dissent, the findings are rather mixed: Faas (2003) notes that this leads to more defection, whereas Klüver and Spoon (2015) found the opposite effect.

MEPs affiliated with larger national party delegations are expected to dissent less because they can influence the EPG's position more in the first place, due to their strength in numbers (Klüver and Spoon 2015). MEPs from new Member States might be more likely to support the directives given the 'new Europe vs. old Europe' divide, while previous studies have also shown they dissent more (Lindstädt et al. 2012). Given that the Grand Coalition of EPP and PES was essential in the adoption of the directives, we expect their members to support them and dissent less. We expect the same for MEPs of the EPGs which nominated the rapporteurs, because those EPGs had higher stakes in the directives' passage and might have exerted more pressure on their members.

\section{Research design}

The article analyzes all 28 roll-call votes taken on the two directives: 8 votes in 2005 and 20 in 2016. They include both votes on amendments and final votes on the directives. We combine the 
votes (Hix et al.2006; Votewatch) with data on MEPs' parliamentary experience, leadership positions and committee membership (Høyland et al. 2009).

We used the 2004 data set of the Euromanifestos Project (Schmitt and Wüst 2012) and the 2014 EP Election Study manifesto data (Schmitt et al. 2016) for comparable measures of the parties' placement on the left-right and EU integration scales and the salience assigned by parties to human rights, constitutionalism and law and order.

\section{Methods}

Because we seek to explain both what made MEPs support the directives and what motivated their dissent from the EPG line we ran two series of models. The first set are OLS regressions which have as their dependent variable an aggregate liberty-security vote score based on our coding of the amendments. The second set are binary logistic regressions which have as their DV a dichotomous variable coded 1 if the MEP dissented. We ran the dissent models on the long format of the datasets, each observation representing a vote decision. Since dissent implies a party line to defect from, non-attached MEPs were excluded from the dissent models.

\section{Variables}

For the DV used in the first set of models each 'yes' vote was coded on a -2 (pro liberty) to +2 (pro security) scale, according to the overall direction of the vote. Amendments were collected from the EP website and from the website of the European Digital Rights network. Amendments suggesting an increase in the power of national authorities to collect and access data were coded either as 'moderately pro-security', receiving a score of 1, or as 'highly pro-security', receiving a score of 2, while amendments reducing that power were coded either as 'moderately pro liberty', 
receiving a score of -1 or as 'highly pro-liberty', receiving a score of -2 . For a discussion regarding the amendments' contents, and detailed explanations of each coding decision, see the Online Appendix 1. We did not want to infer a substantial pro security or pro liberty position from 'No' votes and abstentions, thus we coded them as 0 , which can be translated as a preference for the status quo. The DV of the models presented in Table 1 is simply the sum of these coded votes.

Dissent, the DV of the models in Table 2, is coded 1 if the MEP voted differently from the majority of the EPG members. As the PNR directive required an absolute majority of votes to be passed and because for the DRD there were also cases when the majority of the EPG abstained, we also included abstentions in coding dissent. Thus, we decided to code abstentions ${ }^{7}$ as dissent when the majority of the EPG voted 'yes' or 'no' and to code substantive votes as dissent when the majority of the EPG abstained. Absent MEPs and those present but not voting were coded as missing. These coding decisions follow common practice (Lindstädt et al. 2012).

The ideological distance variables and the variables measuring the differences in issue salience between the national party and the EPG use as measures for EPG positions the average position/ issue salience of their component national parties weighted by the number of MEPs from each party. Each of these variables is computed by subtracting the value of the MEP's national party scale placement (for the ideological distance variables) or issue salience from the corresponding EPG measure. Since direction is bound to matter we use the raw values of the subtractions.

\footnotetext{
7 The online appendix includes separate analyses of the determinants of abstentions, which show that in our cases the causes were similar to those of dissent.
} 
Membership in a relevant committee is a dummy coded 1 if the MEP was member of a committee dealing with the directives: the Civil Liberties, Justice and Home Affairs in both 2005 and 2016; the Industry, Research and Energy committee and the Internal Market and Consumer Protection committee (opinions in 2005); the Foreign Affairs and the Transport and Tourism committees (opinions in 2016).

Electoral marginality subtracts the number of seats won by the candidate's party in the EP constituency from the MEP's list position or vote ranking in the case of countries using preferential voting systems. ${ }^{8}$ The variable assumes negative values for all candidates who had a safe election, 0 for those assigned the last seat won by their party and positive values for the MEPs elected because a colleague did not take up the seat or resigned.

National Party in government is a dummy variable coded 1 if the MEP's party was in the national executive at the time of the votes, based on the PARLGOV project (Döring and Manow 2016). EPG leadership position is coded 1 if the MEP was a chair, vice-chair, treasurer or member of the bureau of her EPG. Similarly, EP leadership position is a dummy variable coded 1 for MEPs who were EP president or vice-presidents, members of the Parliament's bureau or of the Conference of Presidents.

\section{What explains voting in favor of the directives?}

Table 1 below presents the findings of the OLS regression models regarding the MEPs' likelihood to support the directives. The amount of variance explained the models ranges from $50 \%$ for the DRD votes to approximately $57 \%$ for the PNR votes.

\footnotetext{
${ }^{8}$ This measure is similar to the one used by Bowler and Farrell (1993).
} 
As expected, MEPs from Europhile parties voted overwhelmingly in favor of the directives and of the pro-security amendments compared to members of Eurosceptic parties. MEPs affiliated with more authoritarian national parties voted in favor of the data retention directive more than did those belonging to libertarian parties. Overall, our first hypothesis is corroborated: national parties' positions on the EU dimension matter more than their placement on the GAL-TAN axis. Thus, a complete switch on the EU integration dimension (from the most Eurosceptic to the most Europhile party) produces an effect for the DRD votes which is two points higher than the effect of a full switch on the GAL-TAN axis, whereas for the PNR directive the latter variable does not reach statistical significance. Conversely, for the DRD regression the maximum effect of the GAL-TAN variable is 1 point larger than that generated by a full switch on the left-right axis.

The salience associated with one issue mattered greatly in both series of votes: MEPs from parties which emphasize human rights opposed the directives and the extension of surveillance much more than other MEPs. The salience assigned to constitutionalism did not matter for the opposition to the directives. In an alternative specification, we replaced the GALTAN position with the salience assigned by the national parties to law and order issues. This variable had the expected positive effect on the likelihood of voting in favor of both directives. ${ }^{9}$

Some of the control variables produce notable effects. First, the more right-wing their national party, the more likely the MEPs were to vote in favor of the two directives. Second, MEPs whose parties were in government voted more frequently in favor of the amendments proposing increased surveillance at the DRD votes. Third, Grand Coalition MEPs and those affiliated with the same EPG as the rapporteur voted more often in favor of the directives.

\footnotetext{
${ }^{9}$ We cannot include both variables simultaneously in these models because of multicollinearity.
} 
Regarding the latter there is however a clear difference in enthusiasm between ALDE MEPs in 2005 (whose rapporteur heavily criticized the final form of DRD) and the ECR MEPs in 2016. Membership of a relevant committee and an affiliation with a new member state delegation did not make any difference.

Table 1: Determinants of voting in favor of higher security options on the Data Retention and PNR Directives (OLS Regressions)

\begin{tabular}{lll}
\hline & $\begin{array}{l}\text { Data } \\
\text { Retention }\end{array}$ & PNR \\
\hline NP position: EU integration & $0.056^{* * *}$ & $0.195^{* * *}$ \\
& $(0.011)$ & $(0.029)$ \\
NP position: GAL-TAN & $0.080^{*}$ & 0.056 \\
& $(0.042)$ & $(0.036)$ \\
Salience of Human rights for NP & $-0.720^{* * *}$ & $-0.429 * * *$ \\
& $(0.115)$ & $(0.066)$ \\
Salience of Constitutionalism for NP & -0.035 & 0.270 \\
& $(0.046)$ & $(0.519)$ \\
NP position: Left - right & $0.040^{* *}$ & $0.084 * * *$ \\
& $(0.016)$ & $(0.021)$ \\
Membership in a relevant committee & -0.039 & 0.265 \\
& $(0.398)$ & $(0.508)$ \\
National Party (NP) in government & $2.282^{* * *}$ & 0.619 \\
& $(0.468)$ & $(0.467)$ \\
MEP from New Member State & -0.013 & 0.312 \\
& $(0.558)$ & $(0.467)$ \\
Grand Coalition MEP & $6.304 * * *$ & $10.239 * * *$ \\
& $(0.674)$ & $(0.745)$ \\
MEP same EPG as rapporteur & $1.903 * *$ & $10.738^{* * *}$ \\
& $(0.861)$ & $(0.849)$ \\
Constant & $3.865 * * *$ & $4.987 * * *$ \\
& $(0.837)$ & $(0.810)$ \\
\hline $\mathrm{R}^{2}$ & .499 & .568 \\
Observations & 614 & 657 \\
\hline Significance at ${ }^{+} \mathrm{p}<0.10, * \mathrm{p}<0.05, * * \mathrm{p}<0.01, * * * \mathrm{p}<0.001$ \\
**Robust standard errors in parentheses & & \\
& & \\
& & \\
& &
\end{tabular}

In order to check the robustness of these findings we ran the models on the long format of the dataset (all 17,516 vote decisions), using a binary DV which indicated whether an MEP supported the more pro-security option or not in that vote. In doing so we used binary logistic 
regressions with robust standard errors clustered on MEPs. The main effects discussed above were fully corroborated, both in terms of direction and magnitude.

\section{Determinants of dissent on the two directives}

Before exploring dissent causes it is worth mentioning that the DRD generated more rebellion than the PNR regulations: almost $18 \%$ of the vote decisions were defections from the EPG line compared to only $8 \%$ in 2016 . Moreover, the variation in how much dissent the EPGs faced was much smaller in the case of the DRD votes, when dissent was more evenly distributed than in the case of the PNR votes. Because the DRD was approved with a smaller majority of votes, one could argue that dissent was significantly more costly then than it was at the PNR votes. Examining the EPGs positions' in the EP debates on the two directives is useful for understanding individual motivations of dissent. Due to space constraints we do not discuss them here but they are included in Online Appendix 2.

The first binary logistic regression in table 2 analyzes the determinants of dissent in the 4,686 vote decisions made by MEPs on the DRD. They correctly predict up to $83 \%$ of these decisions. The second regression analyzes the determinants of dissent in the 12,414 vote decisions made by MEPs on the PNR directive. The share of decisions correctly predicted by the models is $92 \%$.

As hypothesized, the larger the distance between the MEP's national party and her EPG, the more likely she is to dissent from the EPG line. Generally, the probability of dissent is higher the more anti-EU the national party is in comparison to the EPG. Similarly, we observe more dissent when the EPGs and national parties assign different salience to law and order issues and to human rights (for the PNR directive). We explore the EU integration distance and law and order effects in more detail below, using predicted probability graphs. 
MEPs from parties closer to the TAN end of the GAL-TAN axis tend to dissent more. In models not shown here we also included an interaction between the GAL-TAN position of the national party and the difference in salience assigned by EPG and national party to law and order. For the DRD model this interaction was significant and it increased the explained variance, while for the PNR model it did not make any difference. In another alternative model specification, we added a variable indicating the distance between the EPG and the national party on the GAL-TAN axis. This variable was multicollinear with the national party's GAL-TAN position, and it did not improve the model fit.

Greater ideological distance on the left-right scale between the national party and the EPG also significantly increases the likelihood of dissent. Generally, the probability of dissent is higher the more the EPG is to the right of the national party. The results also corroborate the socialization effect found in previous studies on voting dissent in the EP: as expected, senior MEPs are significantly less prone to defect. Electorally marginal MEPs were less likely to dissent from the EPG on the PNR directive but the effect was not very strong. The models also indicate that MEPs from larger national party delegations dissent less, probably because they have a greater say in defining their EPG's position than those representing smaller parties. At the same time, leadership positions at the level of the EPG or the Parliament do not make a difference, as is the case for membership in a relevant committee. The different results regarding the likelihood of dissent for the MEPs affiliated with the EPG of the rapporteur reflect the different manner in which the two rapporteurs perceived the final forms of the two directives. 
Table 2: Determinants of Dissent on the Data Retention and PNR Directives (Binary Logistic Regressions) $)^{10}$

\begin{tabular}{lll}
\hline & $\begin{array}{l}\text { Data } \\
\text { Retention }\end{array}$ & PNR \\
\hline Distance EPG - NP: EU integration & $1.034^{* * *}$ & $1.085^{* * *}$ \\
Salience EPG - NP: Human rights & 1.030 & $0.839^{* * *}$ \\
Salience EPG - NP: Law \& order & $1.159 * *$ & $1.234^{* *}$ \\
Salience EPG - NP: Constitutionalism & 1.026 & 0.805 \\
Distance EPG - NP: Left - right & $1.045^{* * *}$ & $1.043^{* *}$ \\
NP position: GAL-TAN & $1.129 * * *$ & $1.074^{* * *}$ \\
Years in European Parliament & $0.947^{*}$ & $0.937^{*}$ \\
EPG leadership position & 0.910 & 1.106 \\
EP leadership position & 1.075 & 0.813 \\
Electoral marginality & 1.051 & $0.876^{* * *}$ \\
Membership in a relevant committee & 1.285 & 1.258 \\
Size of national party delegation in EP & $0.969 *$ & $0.964 *$ \\
National Party (NP) in government & 1.043 & $1.756^{*}$ \\
MEP from New Member State & 0.829 & $0.371 * *$ \\
Grand Coalition MEP & 0.915 & $0.339^{* * *}$ \\
MEP same EPG as rapporteur & $4.733^{* * *}$ & $0.076^{* * *}$ \\
\hline \% Correctly predicted & 83.1 & 92.1 \\
McFadden's R ${ }^{2}$ & .159 & .210 \\
Observations & 4686 & 12414 \\
\hline * Significance at ${ }^{+} \mathrm{p}<0.10, * \mathrm{p}<0.05, * * \mathrm{p}<0.01, * * * \mathrm{p}<0.001$ \\
** Cell entries are odds ratios; models ran with robust standard errors clustered around MEPs
\end{tabular}

In contrast to the usual narrative regarding increased dissent among accession country legislators (Lindstädt et al. 2012), MEPs from new Member States were significantly less likely to dissent on the PNR directive: their probability of defection was almost three times smaller than that of their colleagues from 'old Europe'.

Figure 1, below, created based on the DRD model in Table 2, plots the predicted probability of dissent, with $95 \%$ confidence intervals, against the values of the variable measuring the difference in salience of law and order, while keeping all other variables at their mean. The figure also includes a rug to illustrate where most cases are located. Figure 1 shows that MEPs

\footnotetext{
${ }^{10} \mathrm{We}$ also ran the models in table 2 with country dummies and robust standard errors clustered on the EPGs and the substantive results are virtually identical.
} 
have an increased dissent probability when their EPG places more emphasis on law and order issues than the national party. When the reverse is the case, the probability of dissent is almost 0 .

Figure 1: Probabilities of dissent: differences in salience of law and order (2005)

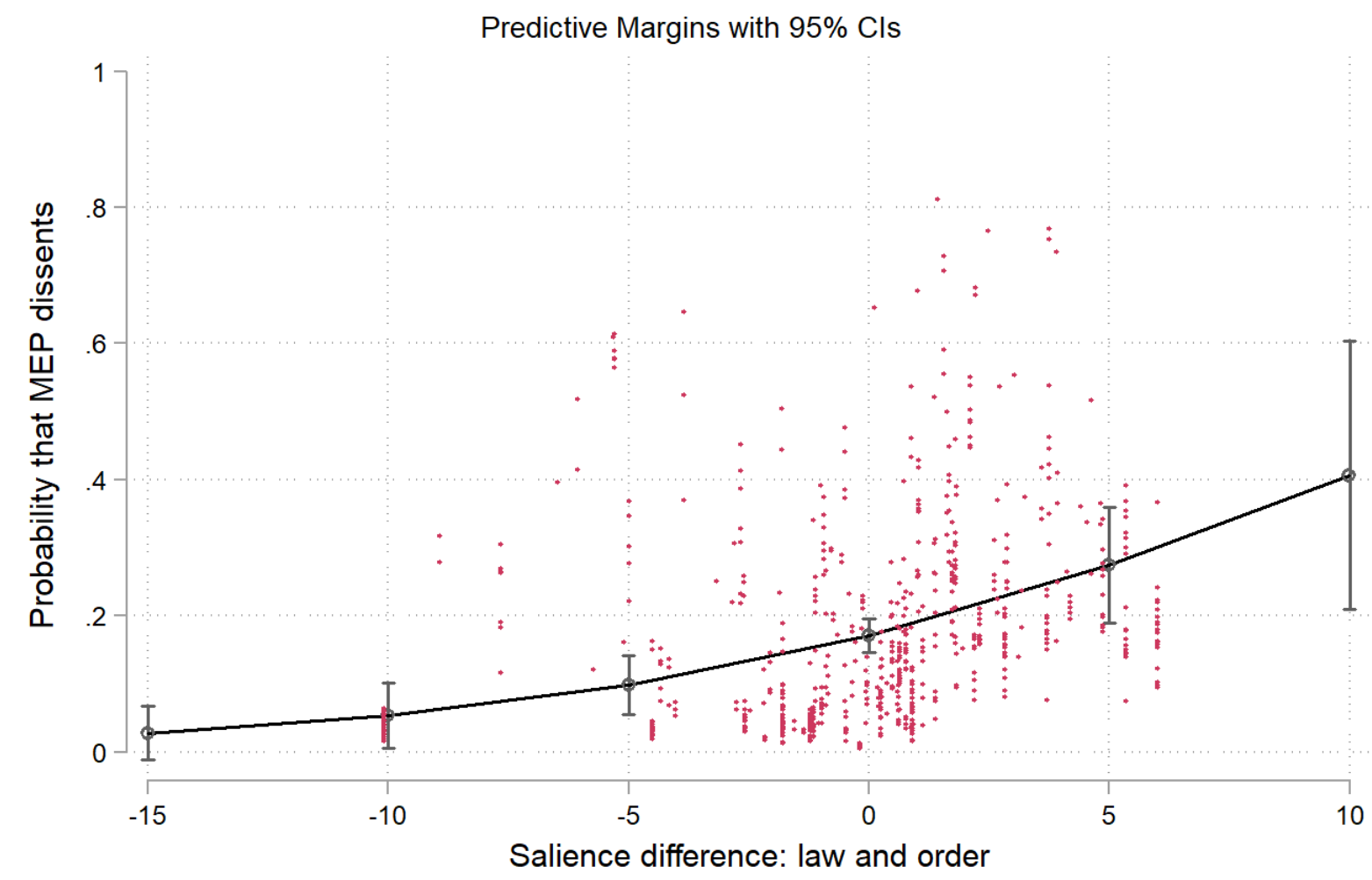

Figure 2 is another margins plot, created based on the PNR model in Table 2. The left-hand panel illustrates how much the likelihood of dissent increases when the national party of the MEP is markedly more Eurosceptic ${ }^{11}$ than the EPG or when the EPG is very pro-European while the national party has a more neutral position. Thus, at the highest positive distance on the EU integration scale the probability of dissent is almost $70 \%$ higher than the situation in which there is no difference in salience or the EPG is significantly more anti-EU than the national party.

${ }^{11}$ Originally the pro vs. anti-EU variable was measured on a scale running from -100 (anti-EU) to 100 (pro EU). 
Figure 2: Probabilities of dissent - EU integration distance and Human rights salience EPG - NP (2016)
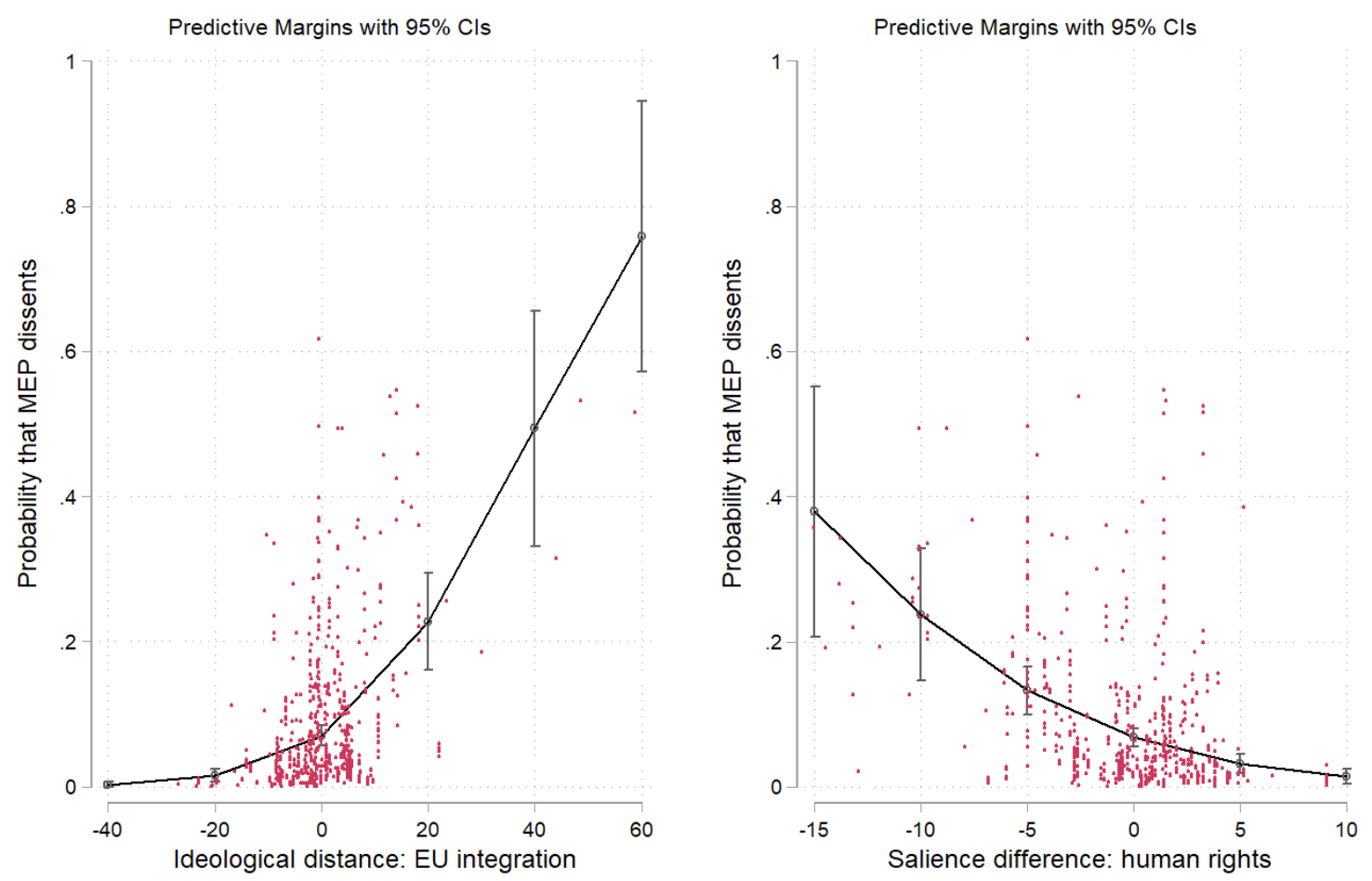

Finally, the right-hand panel of Figure 2 shows that dissent was also more likely when the national party emphasized human rights issues to a greater extent than the EPG: at the peak of this difference in salience, MEPs had an approximately $40 \%$ higher probability of dissenting than their colleagues.

\section{Conclusions}

This paper provides the first analysis of individual legislator voting behavior in the EP in the field of security policy. It does so by focusing on two highly important directives, which differed, however, in the degree of controversy and the scope of dissent they generated.

Generally, the main effects are stronger and the model fit is better for the analyses of the PNR directive than for those of the DRD. Part of the explanation might be related to the institutional 
controversy generated by the DRD (see the above discussion regarding the differences between the text adopted by the LIBE committee and the version adopted in the plenary). Nevertheless, it is also reasonable to believe that by the time of the adoption of the PNR directive all relevant actors in the EP (EPGs, national parties and even individual MEPs) had learned more about the costs and pay-offs of their decisions on highly salient issues in the area of security policies, both with respect to their negotiations with other actors in the EU institutional architecture and with respect to the likely reactions of national media and citizens.

Another insight that the paper brings is that, on such issues, a national party's placement on the pro vs. anti-EU and GAL-TAN axes explains its MEPs' votes to a far greater extent than the leftright dimension. Furthermore, as might have been expected, Europhile parties support more community-wide legislation, while parties that are closer to the GAL pole of the GAL-TAN continuum tend to oppose extending surveillance powers. These findings become more relevant in the context of the discussions regarding the future "social contract" on surveillance. Given the current and foreseeable development of technology and surveillance power, it can be expected that these issues will remain highly contested in the future and that the lines of political contestation will follow the above-mentioned ideological divides more closely.

The study reinforces the argument that issue salience should be accounted for in models of EP voting behavior (Klüver and Spoon 2015) by illustrating that differences in issue salience between the national party and the European Party Group mattered for dissent in the two series of votes.

Our results show that the influence of the EPG principal on how MEPs vote is smaller when the national party principal assigns greater issue salience to the topic debated than the EPG. It is plausible to believe that this pattern holds beyond liberty/security topics, particularly for issues 
that cannot be easily integrated on the left-right dimension, on which EPGs are generally homogeneous (Hix et al 2006). Beyond testing this conjecture, future studies could also focus on the mechanism behind it: do national parties issue voting instructions more often on topics carrying such differences in issue salience?

Normatively, it is good news for the chains of delegation and accountability at EU level, in that the positions advertised by national parties in the European Parliament election manifestos account to a large extent for how the MEPs vote on two of the most salient directives in the Area of Freedom, Security and Justice. Nevertheless, the high level of programmatic responsiveness observed might be partly due to greater media attention to these directives (Mühlböck 2012) and consequently more interest on the part of voters. Indeed, future studies could explore how national media coverage and public opinion regarding surveillance and terrorism affect the behavior of MEPs. 


\section{References}

Bowler, S. and Farrell, D.M., 1993. Legislator Shirking and Voter Monitoring: Impacts of European Parliament Electoral Systems upon Legislator-Voter Relationships. JCMS: Journal of Common Market Studies, 31(1): 45-70.

Balzacq, T. and Leonard S. 2013. Information-sharing and the EU Counter-terrorism Policy: A 'Securitisation Tool' Approach. In Kaunert, C. and Leonard, S. European Security, Terrorism and Intelligence Tackling New Security Challenges in Europe, Houndmills: Palgrave: $127-142$

Brack, N. 2015. The roles of Eurosceptic Members of the European Parliament and their implications for the EU. International Political Science Review, 36(3), 337-350.

Coman, E.E., 2009. Reassessing the influence of party groups on individual members of the European Parliament. West European Politics, 32(6): 1099-1117.

Döring, H. and Manow, P. 2016. Parliaments and governments database (ParlGov): Information on parties, elections and cabinets in modern democracies. Development version.

Faas, T. 2003. To defect or not to defect? National, institutional and party group pressures on MEPs and their consequences for party group cohesion in the European Parliament. European Journal of Political Research,42(6): 841-866

Gherghina, S. and Chiru, M., 2014. Determinants of legislative voting loyalty under different electoral systems: Evidence from Romania. International Political Science Review, 35(5): 523-541.

Hix, S.2002. Parliamentary behavior with two principals: Preferences, parties, and voting in the European Parliament. American Journal of Political Science 46(3): 688-698. 
Hix, S. 2004. Electoral institutions and legislative behavior: Explaining voting defection in the European Parliament. World Politics, 56(2): 194-223.

Hix, S., and Noury, A. 2007. Politics, Not Economic Interests: Determinants of Migration Policies in the European Union. International Migration Review, 41(1): 182-205.

Hix, S., and Høyland, B. 2013. Empowerment of the European Parliament. Annual Review of Political Science, 16: 171-189.

Hix, S., Noury, A. and Roland, G. 2006. 'Dimensions of Politics in the European Parliament', American Journal of Political Science, 50(2): 494-511.

Hooghe, L., Marks, G. and Wilson, C.J., 2002. Does left/right structure party positions on European integration?. Comparative Political Studies, 35(8): 965-989.

Høyland, B., Sircar, I., and Hix, S. 2009. An Automated Database of the European Parliament, European Union Politics, 10(1): 143-152.

Klüver, H. and Spoon, J.J. 2015. Bringing salience back in: Explaining voting defection in the European Parliament. Party Politics, 21(4): 553-564.

Lindstädt, R., Slapin, J.B. and Wielen, R.J.V., 2012. Adaptive behaviour in the European Parliament: Learning to balance competing demands. European Union Politics, 13(4): 465-486.

Marks, G., and Steenbergen, M. 2002. Understanding Political Contestation in the European Union. Comparative Political Studies, 35(8): 879-892.

Monar, J. 2014. „EU internal security governance: the case of counterterrorism”, European Security, 23 (2): 195-209

Mühlböck, M., 2012, "National versus European: Party Control over Members of the European Parliament", West European Politics, 35(3): 607-631 
Yordanova, N. and Mühlböck, M., 2015. Tracing the selection bias in roll call votes: party group cohesion in the European Parliament. European Political Science Review, 7(3), pp.373399.

Otjes, S. and van Der Veer, H., 2016. The Eurozone crisis and the European Parliament's changing lines of conflict. European Union Politics, First View.

Poitras. 2013. How the NSA Targets Germany and Europe, available at: http://www.spiegel.de/international/world/secret-documents-nsa-targeted- germany-andeu-buildings-a-908609.html

Rasmussen, A., 2008. Party soldiers in a non-partisan community? Party linkage in the European Parliament. Journal of European Public Policy, 15(8), pp.1164-1183.

Ripoll Servent, A., 2013. Holding the European Parliament responsible: policy shift in the Data Retention Directive from consultation to codecision. Journal of European public policy, 20(7): 972-987.

Ripoll Servent, A. and MacKenzie, A., 2011. Is the EP still a data protection champion? The case of SWIFT. Perspectives on European politics and society, 12(4): 390-406.

Ripoll Servent, A., and MacKenzie, A., 2017. Eroding Germany's Commitment to Data Protection: Policy Entrepreneurs and Coalition Politics in EU Passenger Name Records. German Politics, 26(3): 398-413.

Ripoll Servent, A. 2015. Institutional and Policy Change in the European Parliament Deciding on Freedom, Security and Justice, Houndmills: Palgrave.

Roger, L, Otjes, S. and van Der Veer, H. 2017.The financial crisis and the European Parliament: An analysis of the Two-Pack legislation. European Union Politics, First View. 
Schmitt, H., Braun, D, Popa, S., Mikhaylov, S. and Dwinger, F. 2016. European Parliament Election Study 2014, Euromanifesto Study. GESIS Data Archive, Cologne. ZA5162, doi:10.4232/1.5162

Schmitt, H., and Wüst, A. M. 2012. Euromanifestos Project (EMP) 1979 - 2004. GESIS Data Archive, Cologne. ZA4457, doi:10.4232/1.4457

Trauner, F., and Ripoll Servent A. (eds.), 2015. Policy change in the Area of Freedom, Security and Justice: How EU institutions matter, Routledge.

Santos Vara, Juan. 2013. The role of the European Parliament in the conclusion of the Transatlantic Agreements on the transfer of personal data after Lisbon Center for the Law of the EU external relations, Working paper 2/2013, http://www.asser.nl/upload/documents/20130226T013310-cleer_13-2_web.pdf, Accessed 27.08.2018

Stoian, V. 2015.'A comparative analysis of the Jurisprudence of the European Court of Justice and the Romanian Constitutional Court on Metadata Retention', Romanian Intelligence Studies Review, 13: 73-84.

Svendsen, A. 2013. On a 'Continuum with Expansion'? Intelligence Cooperation in Europe in the Early 21st Century. In Kaunert, C. and Leonard. S. European Security, Terrorism and Intelligence Tackling New Security Challenges in Europe, Houndmills: Palgrave: 185214

Yordanova, N., 2013. Organising the European Parliament: The Role of the Committees and their Legislative Influence. ECPR Press.

***Directive 2006/24/EC on the retention of data generated or processed in connection with the provision of publicly available electronic communications services or of public 
communications networks and amending Directive 2002/58/EC, retrieved from:

http://eurlex.europa.eu/LexUriServ/LexUriServ.do?uri=OJ:L:2006:105:0054:0063:EN:P

$\mathrm{DF}$

***Directive (EU) 2016/681 of the European Parliament and of the Council of 27 April 2016 on the use of passenger name record (PNR) data for the prevention, detection, investigation and prosecution of terrorist offences and serious crime. Retrieved from:

http://eurlex.europa.eu/eli/dir/2016/681/oj

***European Parliament. 2005. Debates Tuesday, 13 December 2005 - Strasbourg, http://www.europarl.europa.eu/sides/getDoc.do?pubRef=//EP//TEXT+CRE+20051213+ITEM-055+DOC+XML+V0//EN\&language=EN

***European Parliament, n.d., Legislative train schedule Area of Justice and Fundamental Rights, EU passenger name record (European PNR), http://www.europarl.europa.eu/legislative-train/theme-area-of-justice-and-fundamentalrights/file-eu-passenger-name-record-\%28european-pnr\%29

***European Parliament. 2015. Texts adopted, European Agenda on Security, http://www.europarl.europa.eu/sides/getDoc.do?pubRef=-//EP//TEXT+TA+P8-TA-2015$\underline{O 269+0+D O C+X M L+V O / / E N}$

***European Digital Rights Initiative. 2011. Commission's proposal for PNR Directive fails to impress MEPs, http://history.edri.org/edrigram/number9.3/commission-pnr-directive,

***European Court of Justice, Digital Rights Ireland Ltd (C-293/12) v. Minister for Communications, Marine and Natural Resources, 8.04.2014 retrieved from http://curia.europa.eu/juris/document/document.jsf?text=\&docid=150642\&pageIndex $=0$ \&doclang $=E N \&$ mode $=1$ st $\&$ dir $=\& o c c=$ first $\&$ part $=1 \&$ cid $=125076$ 
